\title{
Probing phosphoric acid redistribution and anion migration in polybenzimidazole membranes
}

Becker, Hans; Cleemann, Lars Nilausen; Aili, David; Jensen, Jens Oluf; Li, Qingfeng

Published in:

Electrochemistry Communications

Link to article, DOI:

10.1016/j.elecom.2017.07.005

Publication date:

2017

Document Version

Peer reviewed version

Link back to DTU Orbit

Citation (APA):

Becker, H., Cleemann, L. N., Aili, D., Jensen, J. O., \& Li, Q. (2017). Probing phosphoric acid redistribution and anion migration in polybenzimidazole membranes. Electrochemistry Communications, 82, 21-24. https://doi.org/10.1016/j.elecom.2017.07.005

\section{General rights}

Copyright and moral rights for the publications made accessible in the public portal are retained by the authors and/or other copyright owners and it is a condition of accessing publications that users recognise and abide by the legal requirements associated with these rights.

- Users may download and print one copy of any publication from the public portal for the purpose of private study or research.

- You may not further distribute the material or use it for any profit-making activity or commercial gain

- You may freely distribute the URL identifying the publication in the public portal 


\title{
Probing phosphoric acid redistribution and anion migration in
}

\section{polybenzimidazole membranes}

\author{
Hans Becker, Lars Nilausen Cleemann, David Aili, Jens Oluf Jensen, Qingfeng Li ${ }^{*}$ \\ Department of Energy Conversion and Storage, Technical University of Denmark,
}

Kemitorvet 207, DK-2800 Kgs. Lyngby, Denmark

*Corresponding Author, Email address: qfil@dtu.dk

\begin{abstract}
Micro platinum electrodes embedded in a laminated phosphoric acid doped polybenzimidazole membrane are employed to monitor the acid migration during hydrogen pump mode operation. Upon application of a constant current, an immediate ohmic resistance decrease of the membrane near the anode is observed, accompanied by a corresponding increase near the cathode side. This is a direct evidence of migration of the acid anions via the vehicle mechanism of the conductivity, resulting in an accumulation of acid molecules at the anode side and depletion at the cathode side. Both resistances reach a steady state value after a prolonged period of measurement, apparently balanced by the back diffusion of the acid molecules. The phenomenon is magnified at higher current densities and with increased thickness of the overall membrane, which is of significance in quantitative understanding of the proton conductivity mechanism e.g. for determination of the anionic transference number. The finding provides a technique to monitor the acid redistribution within the membrane as a basis for an engineering solution to address the long-term durability of fuel cells built around phosphoric acid doped polymer membranes.
\end{abstract}

Keywords: phosphoric acid, polybenzimidazole, transference number, vehicle mechanism, migration, high temperature polymer electrolyte fuel cells 


\section{Introduction}

The high temperature polymer electrolyte membrane fuel cell (HT-PEMFC) has been gaining attention during the past decades due to its tolerance to $\mathrm{CO}$ and $\mathrm{H}_{2} \mathrm{~S}$ impurities present in reformate gases and simple auxiliary units [1-3]. The proton transport is mediated by phosphoric acid doped into the membrane[4,5], usually based on polymers in the polybenzimidazole (PBI) family [6,7]. Nominally dry phosphoric acid shows a low proton conductivity of around $0.09 \mathrm{~S} \mathrm{~cm}^{-1}$ at $50{ }^{\circ} \mathrm{C}$, but it increases up to $0.6 \mathrm{~S} \mathrm{~cm}^{-1}$ when the temperature is increased to $160{ }^{\circ} \mathrm{C}$ [8]. In the acid doped polymer membrane, the conductivity may vary in a range from 0.01 up to $0.2 \mathrm{~S} \mathrm{~cm}^{-1}$ depending on the membrane fabrication procedure [9] and particularly on the phosphoric acid content of the resulting membranes $[10-13]$ and on the partial pressure of water in the atmosphere $[14,15]$.

A unique characteristic of the proton conductivity of phosphoric acid is the high proton transference number $t_{\mathrm{H}+}$ of $97.5 \%$ [16], indicating that Grotthuss-type structure diffusion is the predominating mechanism $[17,18]$. However, recent comprehensive studies show that the transference number strongly depends on the water content [19] and on the presence of other Brønsted bases, such as $N$-heterocycles [20]. The transference number peaks at $100 \mathrm{wt} \% \mathrm{H}_{3} \mathrm{PO}_{4}$ and tends to decrease as the water content increases, not only resulting in increased conductivity but also increased contribution from the vehicular charge transport. At higher concentrations of acid (>100 wt $\%)$, the concentration of cationic species (mainly $\mathrm{H}_{4} \mathrm{PO}_{4}^{+}$) and highly charged phosphate anions (e.g. $\mathrm{H}_{2} \mathrm{P}_{2} \mathrm{O}_{7}{ }^{2-}, \mathrm{H}_{3} \mathrm{P}_{3} \mathrm{O}_{10}{ }^{2-}$ and $\mathrm{H}_{2} \mathrm{P}_{3} \mathrm{O}_{10}{ }^{3-}$ ) increases, which in turn also leads to increased contribution of the vehicle mechanism.

In all cases, the vehicle mechanism of proton conductivity causes migration of the acid [21]. It has been known from the days of phosphoric acid fuel cells that the acid movement due to anion migration poses a crucial problem of acid management [22]. This is 
apparently also of critical concern for the phosphoric acid doped PBI membrane fuel cells, where it causes dramatic redistribution of the phosphoric acid with the membrane-electrode assembly at high current loads [23]. At temperatures above $160{ }^{\circ} \mathrm{C}$ and at higher current loads than $200 \mathrm{~mA} \mathrm{~cm}^{-2}$, the phosphoric acid was found to penetrate through the catalyst and gas diffusion layers leading to significant acid leaching [24].

This work is devoted to probing the acid redistribution within the PBI membrane by micro reference electrodes integrated in the membrane electrolytes. The configuration allows for a direct measurement of the ohmic resistance through different segments of the membrane, as an indicator of its acid content change upon a flow of electrical current. Similar method was also done in Nafion-based PEMFC to characterize the profile of the water content during operation $[24,25]$. To simplify the study, the cell is operated in hydrogen pumping mode to exempt the large charge transfer resistance of the oxygen reduction reaction, making the system almost purely ohmic. The presence of hydrogen on both sides of the membrane also enables a stabilized potential of the platinum reference electrodes. This provides a tool for quantitative understanding of the proton conductivity mechanism and evaluation of the acid management issue as a basis for the development of engineering solutions to improve the long-term durability of HT-PEMFC.

\section{Experimental}

A schematic diagram of the membrane electrode assembly (MEA) is shown in Figure 1. The PBI membranes were prepared by solution casting from $N, N$-dimethylacteamide (DMAc),

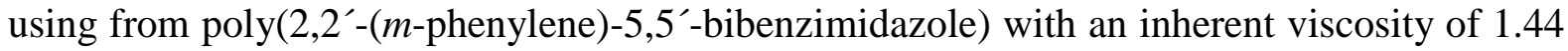
$\mathrm{dL} \mathrm{g}^{-1}\left(500 \mathrm{mg} \mathrm{dL}^{-1}\right.$ in $96 \% \mathrm{H}_{2} \mathrm{SO}_{4}$ at $30.0{ }^{\circ} \mathrm{C}$ ) as prepared according to protocols reported in the literature [27]. After extensive washing in demineralized water, the PBI membranes were 
equilibrated in $85 \% \mathrm{H}_{3} \mathrm{PO}_{4}$ (Sigma-Aldrich) at room temperature for two weeks to give an acid content of around 10 molecules of $\mathrm{H}_{3} \mathrm{PO}_{4}$ per polymer repeat unit.

The electrodes were prepared by spraying Pt/C (60 wt\% Johnson Matthey HiSPEC 9100) dispersed in ethanol on a carbon cloth pre-coated with a microporous layer (Freudenberg $\mathrm{H} 23 \mathrm{C} 2$ ). Platinum loading of $1 \mathrm{mg} \mathrm{cm}^{-2}$ was used for both electrodes. The segmented MEAs with integrated reference electrodes were prepared using 3 laminated membrane layers as shown schematically in Figure 1.

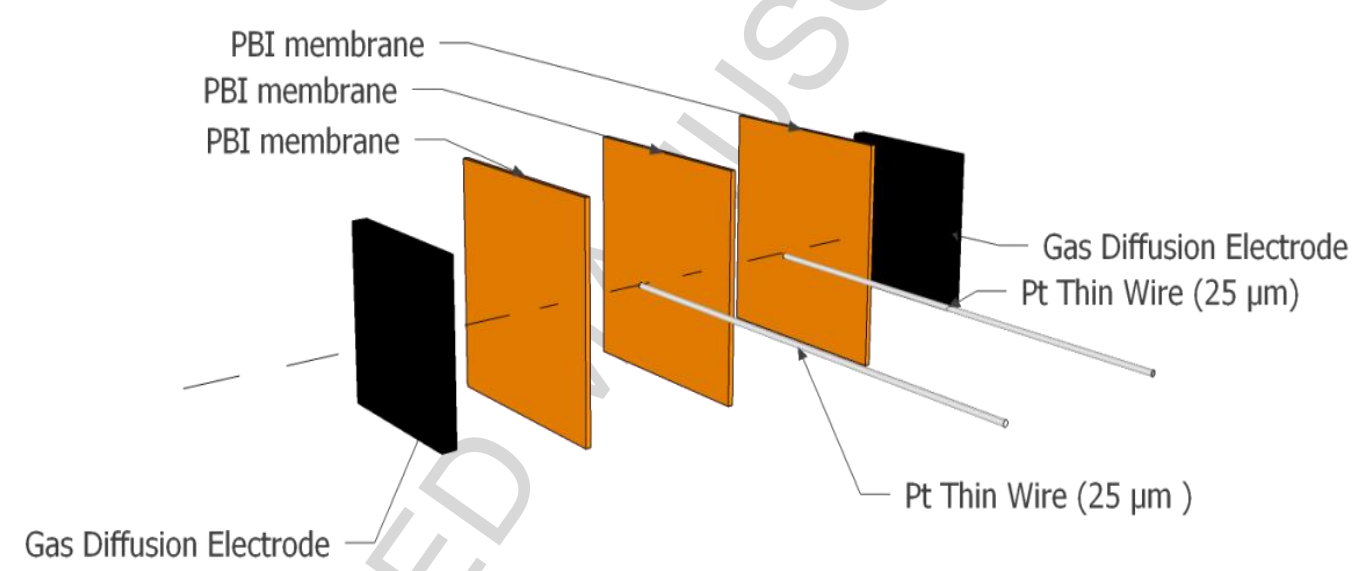

Figure 1 Schematic drawing of the MEA of multilayered membranes with integrated reference electrodes.

The layers are hereafter referred to as A (anode side), $\mathrm{M}$ (middle), and $\mathrm{C}$ (cathode side). The thickness of layer A and C was kept constant at $40 \mu \mathrm{m}$, while layer M was either 40 or 120 $\mu \mathrm{m}$. Insulated platinum wires (diameter $=25 \mu \mathrm{m}, 5 \mu \mathrm{m}$ polyimide insulation) were placed at the center of the active area and sandwiched between the interfaces of membrane layers, as shown in Figure 1. The insulation coating at the wire tip located between membranes were burned off beforehand and treated with $5 \mu \mathrm{L}$ of $2 \mathrm{wt} \%$ PBI in DMAc twice. Excess DMAc 
was evaporated in a fumehood, leaving a film of the polymer on the Pt to improve the ionic contact. Under a flow of hydrogen on both electrode side, the permeated hydrogen stabilizes the potentials of two platinum reference electrodes (ranges from 0 to $3 \mathrm{mV}$ at open circuit voltage). The MEAs were assembled by sandwiching the laminated membranes between the two electrodes with an area of $3.1 \times 3.1 \mathrm{~cm}^{2}$. The active area was $8.8 \mathrm{~cm}^{2}$, since frames of polysulfone were used as reinforcement around the electrode edges. The electrochemical impedance spectroscopy data were acquired using a VersaStat 4 potentiostat from Princeton Applied Research, at $5 \mathrm{mV}$ amplitude in the frequency range 2500-75 Hz. The ohmic resistance was taken at the intersection with the real axis in the Nyquist plot. Measurements during open circuit voltage (OCV) were taken to calibrate the exact position of $\mathrm{Pt}$ wires.

The cell housing consisted of two aluminum end plates with heating elements and current collectors. Clamping was done by tightening four end corners of endplates using 8 mm nuts and bolts. The MEAs were hot pressed within the cell housing at $120{ }^{\circ} \mathrm{C}$ at a torque of $1 \mathrm{Nm}$ for 10 minutes. The cell temperature was subsequently increased to $160{ }^{\circ} \mathrm{C}$ and left under hydrogen flow overnight to let it equilibrate before measurement. The hydrogen flow

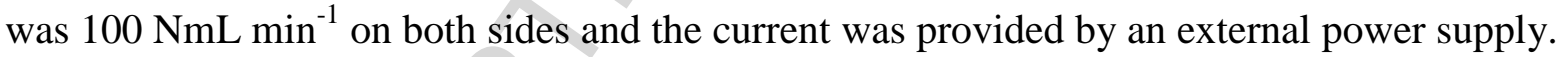

\section{Results and discussion}

The polarization curves for the cells with different thicknesses of the middle layer are shown in Figure 2a. Both cells showed an almost linear slope, which suggests an ohmic-dominant process throughout the whole current density range [27, 28]. Potentiostatic impedance scans of the working cell further showed a very small arc representing the hydrogen oxidation and reduction at the anode and cathode, respectively. 

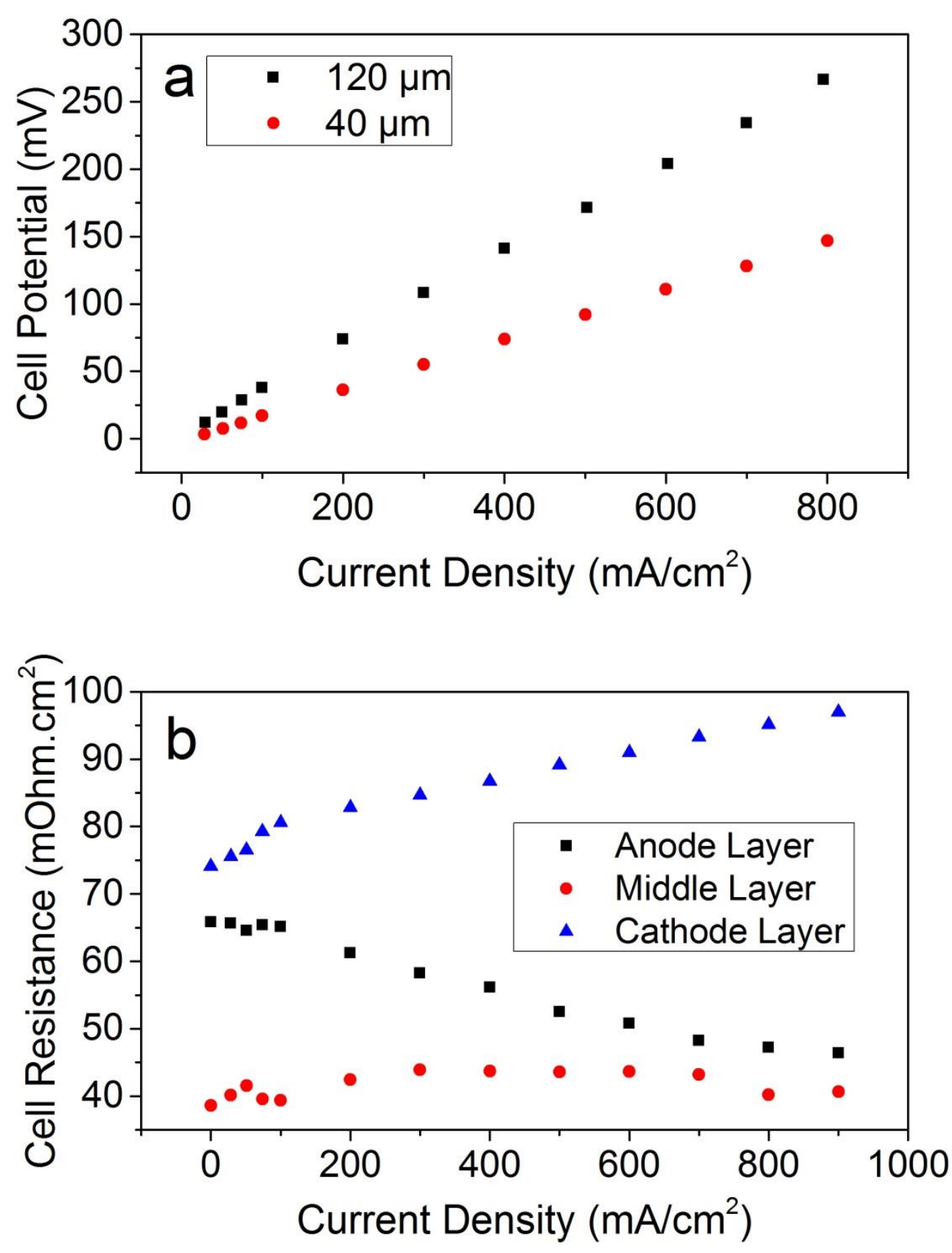

Figure 2 Polarization curves of the cells equipped with middle layers of 40 and $120 \mu \mathrm{m}$ (a) and the corresponding series resistances of different segments at different current densities for the cell with a $40 \mu \mathrm{m}$ middle layer (b). 
The sum of the potentials across different layers corresponded well with the total cell potential. The area specific resistance of the different layers of the segmented MEAs, as obtained from the electrochemical impedance data at different current densities are shown in Figure $2 b$. The resistance of the anode layer $\left(R_{A}\right)$ tended to decrease with increasing current density, while the opposite was observed for that of the cathode layer $\left(\mathrm{R}_{\mathrm{C}}\right)$. The decreasing $\mathrm{R}_{\mathrm{A}}$ can be interpreted as an improvement in conductivity caused by increasing local content of phosphoric acid at the anode side of the MEA. Similarly, growing $\mathrm{R}_{\mathrm{C}}$ was due to local depletion of phosphoric acid on the cathode side of the MEA. At current densities below 100 $\mathrm{mA} \mathrm{cm}{ }^{-2}, \mathrm{R}_{\mathrm{A}}$ decreased slightly while $\mathrm{R}_{\mathrm{C}}$ increased significantly.

The potential across the different layers was monitored over time at current densities of 200,500 , and $800 \mathrm{~mA} \mathrm{~cm}{ }^{-2}$. The change of area specific resistances from OCV to each current densities of the anode and cathode side layers for the cells equipped with the 40 or $120 \mu \mathrm{m}$ middle layer are plotted as functions of time in Figure 3a-b and 3c-d, respectively. The area specific resistance stabilized within a few minutes at all current densities, but with a noticeable longer stabilization period for the cells with a thicker middle layer. This seemed to be more pronounced for the anode side layer, where a steady state was reached after around 10 minutes compared to 3 minutes for the cathode side layer.

Another interesting observation from the data in Figure 3 is that $\mathrm{R}_{\mathrm{A}}$ decreased gradually over time while $\mathrm{R}_{\mathrm{C}}$ increased rapidly and peaked before it decreased again to the steady-state value. The initial $R_{C}$ peak was observed at high current densities, and is likely connected to the inherently fast process of anion migration. The following gradual decrease of $R_{C}$ to reach a steady state value (although still higher than the initial equilibrium value) is probably attributed to diffusive redistribution of the phosphoric acid driven by the concentration gradient. 
Another aspect that should be taken into consideration in this connection is that the cells were operated with dry hydrogen without active humidification at $160{ }^{\circ} \mathrm{C}$. This shifts the equilibrium towards condensation products of the acid $\left(\mathrm{H}_{4} \mathrm{P}_{2} \mathrm{O}_{7}\right.$ and higher oligomers), which also promotes the formation of its corresponding ionic phosphoric oxoacid species (i.e. $\mathrm{H}_{3} \mathrm{P}_{2} \mathrm{O}_{7}{ }^{-}, \mathrm{H}_{4} \mathrm{P}_{3} \mathrm{O}_{10}{ }^{-}$, and others) $[19,20]$. The extreme dryness at this temperature also shifts the acid concentration beyond $100 \mathrm{wt} \%$, which reduces $t_{\mathrm{H}+}$ and amplifies the vehicular transport. It should be remarked that a hydrogen-air HT-PEMFC operating with an air stoichiometry of $\lambda_{\text {air }}=2$ will generate water at the cathode side corresponding to a partial pressure of $\mathrm{P}_{\mathrm{H}_{2} \mathrm{O}} \approx 0.19$ atm, which will make the migration phenomenon much less severe than shown in the present work.
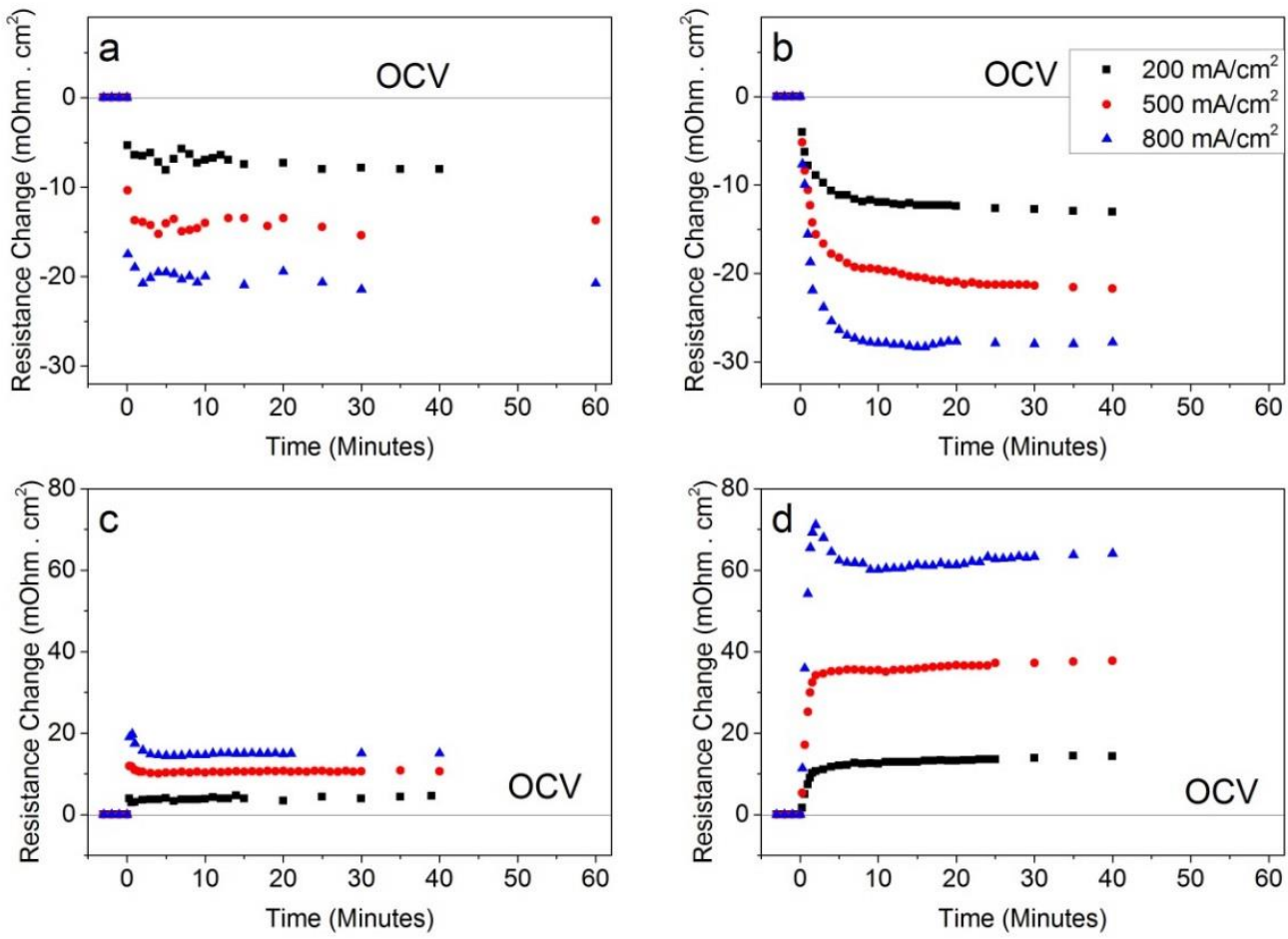

Figure 3 Resistance change from OCV to current densities of 200,500 and $800 \mathrm{~mA} \mathrm{~cm}^{-2}$ as a function of time for the anode side layer at the middle layer thickness of $40 \mu \mathrm{m}$ (a) and 120 $\mu \mathrm{m}$ (b) and for the cathode side layer at the middle layer thickness of $40 \mu \mathrm{m}$ (c) and $120 \mu \mathrm{m}$ (d), respectively. 
Apparently, the phosphoric acid accumulation due to the parasitic flux $\left(J_{\mathrm{i}}\right)$ of acid from the cathode to anode was counter-balanced by the back-diffusion $\left(J_{\mathrm{m}}\right)$ of the acid towards the cathode side driven by the developed concentration gradient. In addition, there is a flux of acid through the catalyst layer towards the gas diffusion layer $\left(J_{\mathrm{GDL}}\right)$. Since a stable performance of hydrogen pumps constructed around this type of electrolyte system has been achieved for nearly $4000 \mathrm{~h}$ at $160{ }^{\circ} \mathrm{C}$ at $200 \mathrm{~mA} \mathrm{~cm}{ }^{-2}$ [28], it can be rationalized that $J_{\mathrm{m}}$ is much larger than $J_{\mathrm{GDL}}$, as the latter would cause acid loss and degradation of the cell performance. At the steady state, the back-diffusion $J_{\mathrm{m}}$ may be estimated by Fick's first law as shown in Equation 1, where $D$ is the diffusion constant, $\left[\mathrm{H}_{3} \mathrm{PO}_{4}\right]$ is the $\mathrm{H}_{3} \mathrm{PO}_{4}$ concentration and $w$ is the thickness of the membrane.

$J_{\mathrm{m}}=\mathrm{D} \times \Delta\left[\mathrm{H}_{3} \mathrm{PO}_{4}\right] / \mathrm{w}$

By comparing Figures $3 \mathrm{c}$ and $\mathrm{d}$ it can be seen that the phosphoric acid depletion on the cathode side is more severe for the cell with a thicker middle or whole membrane. This is apparently a direct consequence of the slow back-diffusion of phosphoric acid from the anode to the cathode. Prolonged resistance stabilization time with thicker membrane further supports this argument. From Equation 1 one expects that $J_{\mathrm{m}}$ decreases as $w$ increases given that the other variables are constant. However, the larger phosphoric acid inventory of the thicker membranes allows for a larger accumulation of phosphoric near the anode followed by the development of a larger concentration gradient $\Delta\left[\mathrm{H}_{3} \mathrm{PO}_{4}\right]$. A higher acid build-up at the anode could also promote $J_{G D L}$, diminishing the equilibrium concentration built up at the anode side. 


\section{Conclusion}

A segmented membrane electrode assembly with embedded reference electrodes was constructed to monitor the redistribution of phosphoric acid within a polybenzimidazole membrane during operation in the hydrogen pumping mode. The ohmic resistance of the membrane was found to decrease near the anode side while it was significantly increased on the cathode side, as a result of accumulation and depletion of phosphoric acid near the anode and cathode, respectively. A steady state was reached within a few minutes when the crosssectional phosphoric acid distribution was counterbalanced by the back-diffusion driven by the concentration gradient. The technique allows for quantitative study of the fundamental mechanism of proton conductivity and technological issues of acid management and longterm durability of phosphoric acid doped PBI membranes in HT-PEM fuel cells.

\section{Acknowledgement}

This work was supported by Innovation Fund Denmark and carried out within 4M Center (sags nr. 0603-00527B).

\section{References}

[1] S. Søndergaard, L.N. Cleemann, J.O. Jensen, N.J. Bjerrum, Influence of carbon monoxide on the cathode in high-temperature polymer electrolyte membrane fuel cells, Int. J. Hydrogen Energy. 42 (2017) 3309-3315. doi:10.1016/j.ijhydene.2017.01.092.

[2] J. Lobato, P. Cañizares, M.A. Rodrigo, J.J. Linares, R. López-Vizcaíno, Performance of a vapor-fed polybenzimidazole (PBI)-based direct methanol fuel cell, Energy and Fuels. 22 (2008) 3335-3345. doi:10.1021/ef8001839.

[3] T.J. Schmidt, J. Baurmeister, Durability and Reliability in High-Temperature 
Reformed Hydrogen PEFCs, ECS Trans. 3 (2006) 861-869. doi:10.1149/1.2356204.

[4] F. Conti, A. Majerus, V. Di Noto, C. Korte, W. Lehnert, D. Stolten, Raman study of the polybenzimidazole-phosphoric acid interactions in membranes for fuel cells, Phys. Chem. Chem. Phys. 14 (2012) 10022-10026. doi:10.1039/c2cp40553a.

[5] X. Glipa, B. Bonnet, B. Mula, D.J. Jones, J. Rozière, Investigation of the conduction properties of phosphoric and sulfuric acid doped polybenzimidazole, J. Mater. Chem. 9 (1999) 3045-3049. doi:10.1039/a906060j.

[6] Q. Li, J.O. Jensen, R.F. Savinell, N.J. Bjerrum, High temperature proton exchange membranes based on polybenzimidazoles for fuel cells, Prog. Polym. Sci. 34 (2009) 449-477. doi:10.1016/j.progpolymsci.2008.12.003

[7] J. Mader, L. Xiao, T.J. Schmidt, B.C. Benicewicz, Polybenzimidazole / Acid Complexes as High-Temperature Membranes, Adv. Polym. Sci. 216 (2008) 63-124. doi:10.1007/12_2007_129.

[8] D.T. Chin, H.H. Chang, On the conductivity of phosphoric acid electrolyte, J. Appl. Electrochem. 19 (1989) 95-99. doi:10.1007/BF01039396.

[9] K.A. Perry, K.L. More, E. Andrew Payzant, R. a. Meisner, B.G. Sumpter, B.C. Benicewicz, A comparative study of phosphoric acid-doped m -PBI membranes, J. Polym. Sci. Part B Polym. Phys. 52 (2014) 26-35. doi:10.1002/polb.23403.

[10] J.S. Wainright, J.-T. Wang, D. Weng, R.F. Savinell, M. Litt, Acid-Doped Polybenzimidazoles: A New Polymer Electrolyte, J. Electrochem. Soc. 142 (1995) L121-L123. doi:10.1149/1.2044337.

[11] R. Bouchet, E. Siebert, Proton conduction in acid doped polybenzimidazole, Solid State Ionics. 118 (1999) 287-299. doi:10.1016/S0167-2738(98)00466-4.

[12] L. Xiao, H. Zhang, E. Scanlon, L.S. Ramanathan, E.-W. Choe, D. Rogers, T. Apple, B.C. Benicewicz, High-Temperature Polybenzimidazole Fuel Cell Membranes via a 
Sol - Gel Process, Chem. Mater. 17 (2005) 5328-5333. doi:10.1021/cm050831+.

[13] R. He, Q. Li, A. Bach, J.O. Jensen, N.J. Bjerrum, Physicochemical properties of phosphoric acid doped polybenzimidazole membranes for fuel cells, J. Memb. Sci. 277 (2006) 38-45. doi:10.1016/j.memsci.2005.10.005.

[14] R. He, Q. Li, G. Xiao, N.J. Bjerrum, Proton conductivity of phosphoric acid doped polybenzimidazole and its composites with inorganic proton conductors, J. Memb. Sci. 226 (2003) 169-184. doi:10.1016/j.memsci.2003.09.002.

[15] Y.-L. Ma, J.S. Wainright, M.H. Litt, R.F. Savinell, Conductivity of PBI Membranes for High-Temperature Polymer Electrolyte Fuel Cells, J. Electrochem. Soc. 151 (2004) A8. doi:10.1149/1.1630037.

[16] T. Dippel, K.D. Kreuer, J.C. Lassègues, D. Rodriguez, Proton conductivity in fused phosphoric acid; A 1H/31P PFG-NMR and QNS study, Solid State Ionics. 61 (1993) 41-46. doi:10.1016/0167-2738(93)90332-W.

[17] T. Dippel, K. Kreuer, Proton transport mechanism in concentrated aqueous solutions and solid hydrates of acids, Solid State Ionics. 46 (1991) 3-9. doi:10.1016/01672738(91)90122-R.

[18] L. Vilčiauskas, M.E. Tuckerman, G. Bester, S.J. Paddison, K.-D. Kreuer, The mechanism of proton conduction in phosphoric acid, Nat. Chem. 4 (2012) 461-466. doi:10.1038/nchem.1329.

[19] J.-P. Melchior, K.-D. Kreuer, J. Maier, Proton conduction mechanisms in the phosphoric acid-water system (H4P2O7-H3PO4-2H2O): a 1H, 31P and 17O PFGNMR and conductivity study, Phys. Chem. Chem. Phys. 19 (2017) 587-600. doi:10.1039/C6CP04855B.

[20] J.-P. Melchior, G. Majer, K.-D. Kreuer, Why do proton conducting polybenzimidazole phosphoric acid membranes perform well in high-temperature PEM fuel cells?, Phys. 
Chem. Chem. Phys. 19 (2017) 601-612. doi:10.1039/c6cp05331a.

[21] D. Aili, R.F. Savinell, J.O. Jensen, L.N. Cleemann, N.J. Bjerrum, Q. Li, The Electrochemical Behavior of Phosphoric-Acid-Doped Poly(perfluorosulfonic Acid) Membranes, ChemElectroChem. 1 (2014) 1471-1475. doi:10.1002/celc.201402053.

[22] T. Murahashi, FUEL CELLS - PHOSPHORIC ACID FUEL CELLS | Electrolytes, Encycl. Electrochem. Power Sources. (2009) 564-567. doi:10.1016/B978-044452745$5.00278-1$.

[23] S.H. Eberhardt, M. Toulec, F. Marone, M. Stampanoni, F.N. Büchi, T.J. Schmidt, Dynamic Operation of HT-PEFC: In-Operando Imaging of Phosphoric Acid Profiles and (Re)distribution, J. Electrochem. Soc. 162 (2015) F310-F316. doi:10.1149/2.0751503jes.

[24] S.H. Eberhardt, F. Marone, M. Stampanoni, F.N. Büchi, T.J. Schmidt, Operando X-ray Tomographic Microscopy Imaging of HT-PEFC: A Comparative Study of Phosphoric Acid Electrolyte Migration, J. Electrochem. Soc. 163 (2016) F842-F847. doi:10.1149/2.0801608jes.

[25] F.N. Büchi, G.G. Scherer, Investigation of the Transversal Water Profile in Nafion Membranes in Polymer Electrolyte Fuel Cells, J. Electrochem. Soc. 148 (2001) A183. doi:10.1149/1.1345868.

[26] M. Watanabe, H. Igarashi, H. Uchida, F. Hirasawa, Experimental analysis of water behavior in Nafion® electrolyte under fuel cell operation, J. Electroanal. Chem. 399 (1995) 239-241. doi:10.1016/0022-0728(95)04323-3.

[27] D. Aili, I. Javakhishvili, J. Han, K. Jankova, C. Pan, S. Hvilsted, J.O. Jensen, N.J. Bjerrum, Q. Li, Amino-Functional Polybenzimidazole Blends with Enhanced Phosphoric Acid Mediated Proton Conductivity as Fuel Cell Electrolytes, Macromol. Chem. Phys. 217 (2016) 1161-1168. doi:10.1002/macp.201600059. 
[28] K.A. Perry, G.A. Eisman, B.C. Benicewicz, Electrochemical hydrogen pumping using a high-temperature polybenzimidazole (PBI) membrane, J. Power Sources. 177 (2008) 478-484. doi:10.1016/j.jpowsour.2007.11.059.

[29] M. Thomassen, E. Sheridan, J. Kvello, Electrochemical hydrogen separation and compression using polybenzimidazole (PBI) fuel cell technology, J. Nat. Gas Sci. Eng. 2 (2010) 229-234. doi:10.1016/j.jngse.2010.10.002. 
Graphical abstract

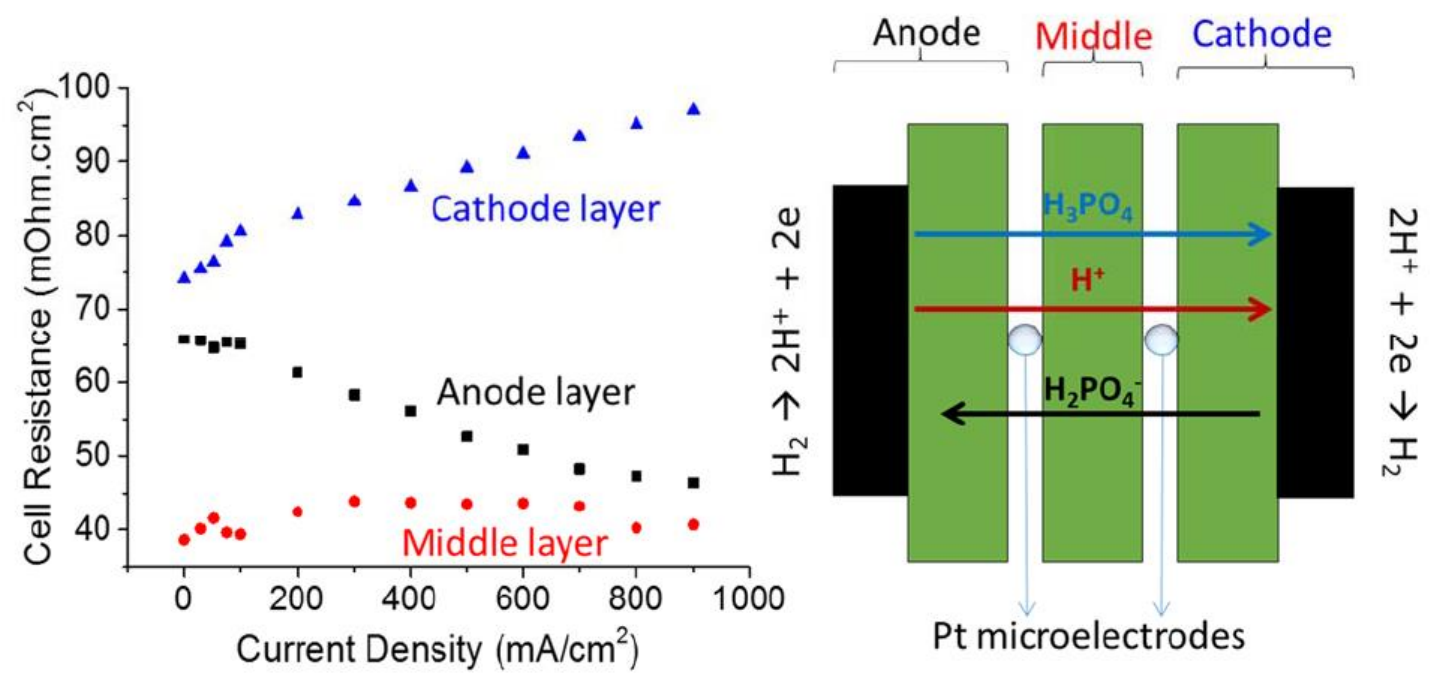




\section{Highlights}

- Embedded Pt microelectrodes in multilayered membranes stabilized under $\mathrm{H}_{2}-\mathrm{H}_{2}$ mode

- Acid migration through membranes monitored by direct resistance measurement

- Anode accumulation and cathode depletion of the acid identified for PBI cells

- A technique developed for probing into proton conducting mechanism 